Barhamudin, Penyalahgunaan Kewenangan Pejabat Pemerintahan Dan Ruang Lingkupnya Menurut Undang-Undang Administrasi Pemerintahan, halaman 175-192

\title{
Penyalahgunaan Kewenangan Pejabat Pemerintahan Dan Ruang Lingkupnya Menurut Undang-Undang Administrasi Pemerintahan
}

\author{
Barhamudin \\ Fakulatas Hukum Universitas Palembang \\ Email : bsuryaigama@yahoo.com
}

\begin{abstract}
The purpose of this research is to find out, study and analyze in determining the element of abusing authority in government administrative laws. In this study using normative research with a statutory approach and a conceptual approach. Legal materials consisting of Primary Legal Materials, Secondary Legal Materials and Tertiary Legal Materials. The results obtained are benchmarks to determine the existence of abuse of authority according to administrative law, in this case UUAP occurs if government officials or officials conduct discretion without going through procedures and the purpose is not carried out within the scope of what has been determined by Law of the Republic of Indonesia Number 30 of 2014 concerning Government Administration in article 17 and article 18 includes: a. The statute goes beyond the authority; b. prohibition of confusing authority; c. prohibition of arbitrary actions. d. beyond the term of office or the validity period of the Authority; e. beyond the territorial validity of the Authority; and / or f. contrary to statutory provisions. $g$ is outside the scope of the field or material given Authority; and / or h. contrary to the stated purpose of the Authority. Abuse of authority either according to administrative law or criminal law has the respective legal domain. Decisions and / or Actions that are determined and / or carried out by exceeding illegitimate Authority if it has been tested and there is a Court Decision that has permanent legal force and Courts that have permanent legal force.
\end{abstract}

Keywords: authority, administra, government

\begin{abstract}
ABSTRAK
Tujuan penelitian ini untuk mengetahui, mengkaji dan menganalisis dalam menentukan unsur menyalahgunakan kewenangan dalam undang-undang administrasi pemerintahan. Dalam penelitian ini menggunakan penelitian normatif dengan pendekatan pendekatan perundang-undangan (statute approach), dan Pendekatan konseptual (concept approach). Bahan hukum yang terdiri Bahan Hukum Primer, Bahan Hukum Sekunder dan Bahan Hukum Tersier. Hasil penelitian diperoleh adalah tolak ukur untuk menentukan adanya penyalahgunaan wewenang menurut hukum administrasi dalam hal ini UUAP terjadi jika aparat atau pejabat pemerintahan melakukan diskresi tanpa melalui prosedur dan tujuan dilakukan tidak dalam ruang lingkup sebgaimana yang telah ditentukan Undang-Undang Republik Indonesia Nomor 30 Tahun 2014 tentang Administrasi Pemerintahan dalam pasal 17 dan pasal 18 meliputi: a.larangan melampaui Wewenang; b. larangan mencampuradukkan Wewenang; c. larangan bertindak sewenang-wenang. d. melampaui masa jabatan atau batas waktu berlakunya Wewenang; e. melampaui batas wilayah berlakunya Wewenang; dan/atau $\mathrm{f}$. bertentangan dengan ketentuan peraturan perundang-undangan. $g$ di luar cakupan bidang atau materi Wewenang yang diberikan; dan/atau $\mathrm{h}$. bertentangan dengan tujuan Wewenang yang diberikan. Penyalahgunaan wewenang baik menurut hukum administrasi ataupun hukum pidana memiliki ranah hukum masingmasing. Keputusan dan/atau Tindakan yang ditetapkan dan/atau dilakukan dengan melampaui Wewenang tidak sah apabila telah diuji dan ada Putusan Pengadilan yang berkekuatan hukum tetap dan Keputusan dan/atau Tindakan yang ditetapkan dan/atau dilakukan dengan mencampuradukkan Wewenang dapat dibatalkan apabila telah diuji dan ada Putusan Pengadilan yang berkekuatan hukum tetap.
\end{abstract}

Kata Kunci : wewenang, administra, pemerintahan 


\section{PENDAHULUAN}

\section{A. Latar Belakang Penelitian}

Satu diantara tujuan bernegara adalah untuk mewujudkan kesejahteraan umum atau rakyat sebagaimana tedapat dalam Pembukaan Undang-Undang Dasar Negara Republik Indonesia Tahun 1945 (UUD NRI 1945). Untuk mewujudkan tujuan negara, penyelenggaraan negara yang dilaksanakan oleh pemerintah yang berdaulat. ${ }^{1}$ Pemerintah yang berdaulat sebagai salah satu unsur negara ${ }^{2}$ diselenggarakan dalam konsep Indonesia sebagai negara hukum. Artinya, pemerintah dalam menjalankan kewenangannya mengatur pemerintahan didasarkan pada landasan peraturan perundang-undangan yang mengikatnya karena kewenangan merupakan kekuasaan yang mempunyai peranan yang dapat menentukan nasib berjuta-juta umat manusia.

Sebagai upaya untuk mensejahterakan rakyatnya, pemerintah dengan birokrasinya menyelenggarakan pelayanan publik bagi masyarakat. Kekuasaan dalam negara modern sebagai manifestasi dari kedaulatan rakyat, sejatinya merupakan amanah rakyat kepada pemegang kekuasaan negara untuk dilaksanakan sesuai dengan tujuan kehidupan bernegara. ${ }^{3}$ Namun, dalam pelaksanannya banyak terjadi penyimpangan dan penyelewengan yang rawan akan terjadinya Korupsi.

Tindak Pidana Korupsi merupakan isu hukum (legal issue) yang menarik untuk dibicarakan pada saat ini, sebab korupsi tidak hanya merugikan

\footnotetext{
${ }^{1}$ Khaelan ,Negara Kebangsaan PancasilaKultural,Historis,Filosofis, Yuridis, dan Aktualisasinya, Yogyakarta, Paradigma, 2013, hal. 50 .

${ }^{2}$ Abu Daud Busroh, Ilmu negara, Jakarta, Bumi Aksara, 2001, hal. 82.

3. Artidjo Alkostar, 2008,Mengkritisi Fenomena Korupsi di Parlemen, Jurnal Hukum, Volume 15, hal. 3.
}

perekonomian Negara, tetapi juga sudah merupakan isu global yang melanda seluruh penjuru dunia, tidak terkecuali Indonesia. Tindak pidana korupsi terus tumbuh dan berkembang, baik kualitas maupun kuantitasnya dengan berbagai modus operandinya. Seiring dengan kemajuan ilmu pengetahuan dan teknologi yang dicapai umat manusia. Saat ini tindak pidana korupsi teindikasi telah memasuki semua lembaga penyelenggara Negara, baik eksekutif, legeslatif, maupun yudikatif, dan berada pada semua tingkatan, baik di tingkat pusat maupun daerah.

Menyadari dampak buruk yang ditimbulkan akibat tindak pidana korupsi, bagi kelangsungan hidup berbangsa dan bernegara, negara-negara di seluruh dunia bertekad memberantas korupsi, mencegah korupsi, dan menanggulangi korupsi. Namun, ironisnya justru tindak pidana korupsi terus tumbuh merajalela di hampir setiap Negara, termasuk Indonesia. Tindak pidana korupsi justru berkembang pesat seolah tidak lekang dimakan zaman, dan bahkan tetap tumbuh subur, khususnya di Indonesia. ${ }^{4}$

"Power tends to corrupt, absolute power corrupts absolutely", hal inilah yang diutarakan oleh sejarawan Inggris, Lord Acton. Semakin besar kekuasaan dan kewenangan seseorang, semakin besar pula potensi melakukan korupsi. Menurut James C. Scott ${ }^{5}$ bahwa korupsi berkaitan dengan kewenangan yang dimiliki. Korupsi yang seringkali berkaitan denganpenyalahgunaan kewenangan oleh pejabat selanjutnya menjadi bahan hukum yang mendasari peraturan perundang-undangan terkait pemberantasan tindak pidana korupsi.

\footnotetext{
4، Prayitno Iman Santosa, PertanggungJawaban Tindak Pidana Korupsi, Alumni, Bandung, 2015, hal. 1.

5 Jawade Hafidz Arsyad, Korupsi dalam Perspektif HAN (Hukum Administrasi Negara), Jakarta, Sinar Grafika, 2013, hal. 72.
} 
Hal ini dapat dilihat dalam Pasal 3 Undang-Undang Nomor 20 Tahun 2001 tentang Perubahan Atas UndangUndang Nomor 31 Tahun 1999 tentang Pemberantasan Tindak Pidana Korupsi, yang mengatur sebagai berikut: ${ }^{6}$ Setiap orang yang dengan tujuan menguntungkan diri sendiri atau orang lain atau suatu korporasi, menyalahgunakan kewenangan, kesempatan atau sarana yang ada padanya karena jabatan atau kedudukan yang dapat merugikan keuangan negara atau perekonomian negara, dipidana dengan pidana penjara seumur hidup atau pidana penjara paling singkat 1 (satu) tahun dan paling lama 20 (dua puluh) tahun dan/atau denda paling sedikit Rp50.000.000,00 (lima puluh juta rupiah) dan paling banyak Rp1.000.000.000,00 (satu miliar rupiah).

Dalam proses penegakan hukum terhadap tindak pidana korupsi, seringkali ditemukan unsur "melawan hukum" dan "menyalahgunakan kewenangan" yang diikuti dengan unsur "kerugian negara" sebagai dasar untuk mendakwa seorang pejabat telah melakukan tindak pidana korupsi semata-mata berdasarkan perspektif hukum pidana tanpa mempertimbangkan bahwa ketika seorang pejabat melakukan aktivitasnya, pejabat tersebut tunduk dan diatur oleh norma hukum administrasi. Seringkali pula ditemukan unsur "merugikan keuangan negara" yang dijadikan dugaan awal untuk mendakwa seorang pejabat tanpa disebutkan terlebih dahulu bentuk pelanggarannya. Suatu pemikiran yang terbalik. Unsur "merugikan keuangan negara" merupakan akibat adanya pelanggaran hukum yang dilakukan seorang pejabat. Seorang pejabat yang menggunakan keuangan negara tidak dapat dikategorikan sebagai tindakan yang "merugikan keuangan negara" jika pejabat yang bersangkutan bertindak sesuai hukum yang berlaku. ${ }^{9}$

Mengenai apa yang dimaksud dengan menyalahgunakan wewenang tidak ada keterangan lebih lanjut dalam undang-undang. Kewenangan hanyalah dimiliki oleh subyek hukum orang pribadi dan tidak ada untuk badan atau korporasi. Kewenangan erat hubungannya dengan jabatan atau kedudukan yang dimiliki oleh seseorang. Diskresi yang pada hakikatnya merupakan kewenangan dari pejabat pemerintahan untuk mengeluarkan keputusan atau melakukan tindakan atas inisiatifnya sendiri tanpa bergantung pada peraturan perundang-undangan yang berlaku sering kali dianggap sebagai penyalahgunaan kewenangan oleh aparat penegak hukum. Tidak adanya peraturan yang jelas mengenai prosedur penggunaan serta batasan-batasan dari diskresi adalah pangkal dari masalahnya.

Sementara pada hakikatnya kewenangan diskresi diberikan kepada pejabat pemerintahan sebagai pelengkap dari aturan perundang-undangan. Karena pada prinsipnya peraturan perundangundangan tidak dapat mengikuti perkembangan dinamika dimasyarakat sehingga diperlukan kemerdekaan bagi pejabat pemerintahan untuk mengeluarkan keputusan secara cepat sesuai dengan persoalan yang dihadapi. Karena tidak mungkin seorang pejabat pemerintahan tidak melakukan sesuatu dengan alasan menunggu sampai dibuatnya suatu aturan atau menunggu suatu aturan yang baru (Rechtsvacuum).

Permasalahan mengenai diskresi sebenarnya telah memasuki wilayah abuabu (grey area) antara hukum administrasi negara dan hukum pidana dengan segala permasalahan dengan proses pemidanaannya, bahkan hingga kini menimbulkan debatabelitas di kalangan ahli hukum pidana, praktisi, maupun akademisi hukum. Dalam ranah hukum administrasi negara, kebijakan pejabat pemerintahan dalam bentuk beleid 
Barhamudin, Penyalahgunaan Kewenangan Pejabat Pemerintahan Dan Ruang Lingkupnya Menurut Undang-Undang Administrasi Pemerintahan, halaman 175-192

(vrijbestuur) maupun diskresi (discretionary power) menjadi ajang kajian akademis untuk dijadikan penolakan maupun justifikasi pemidanaan dalam area hukum pidana.

Diskresi seringkali di mendapat justifikasi sebagai tindak pidana korupsi dalam ranah hukum pidana hal ini biasanya disebabkan oleh beberapa faktor

Faktor pertama, dari segi peraturan perundang-undangan khususnya Undang-Undang Pemberantasan Tindak Pidana Korupsi yang tidak memuat aturan yang jelas bahkan terkesan menimbulkan penafsiran yang begitu luas. Misalnya tidak diaturnya pengertian mengenai penyalahgunaan kewenangan sedangkan penyalahgunaan kewenangan atau dalam Pasal 3 Undang-Undang Pemberantasan Tindak Pidana Korupsi disebut dengan "menyalahgunakan kewenangan" merupakan inti delik (bestanddeel delict) dalam pasal tersebut. Implikasi dari tidak diaturnya pengertian penyalahgunaan kewenangan secara eksplisit dalam hukum pidana khususnya tindak pidana korupsi ialah dapat mengakibatkan tindakan dari pejabat pemerintahan sangat mudah untuk di justifikasi sebagai tindak pidana khususnya terkait dengan kewenangan diskresi yang tidak terikat pada peraturan perundang-undangan karena perbuatan penyalahgunaan kewenangan dapat memunculkan multitafsir dari para penegak hukum. Faktor kedua ialah pemahaman hukum yang keliru dari penegak hukum khususnya dalam memaknai inti (bestanddeel delict) dalam Pasal 3 Undang-Undang Pemberantasan Tindak Pidana Korupsi. Penegak hukum terlalu bergantung dengan unsur "menyalahgunakan kewenangan" dan melupakan bahwa dalam tindak pidana korupsi harus ada yang menerima keuntungan, baik itu individu dari pelaku maupun orang lain atau korporasi. Diskresi sering dipandang sebagai penyalahgunaan kewenangan karena tidak didasari oleh peraturan perundangundangan yang berlaku, padahal semestinya untuk mengkualifikasikan diskresi sebagai penyalahgunaan kewenangan terlebih lagi sebagai tindak pidana korupsi harus ditinjau terlebih dahulu apakah pelaku menerima keuntungan dari diskresi yang dikeluarkannya ataukah ada orang lain yang diuntungkan. Atau dengan kata lain apakah dalam menggunakan kewenangan diskresi tersebut terdapat niat jahat (mens rea) atau tidak dari pelaku. Bagi orang yang memiliki jabatan atau kedudukan tertetu atau orang yang memiliki kualitas pribadi tertentu. $^{7}$

Perbuatan menyalahgunakan wewenang terjadi, apabila seseorang memiliki kewenangan berdasarkan ketentuan atau kebiasaan umum yang berlaku yang melekat pada suatu kedudukan/jabatan yang dipangkunya digunakan secara salah/menyimpang/bertentangan dengan maksud dan tujuan dari diberikannya kewenangan dari kedudukan atau jabatan tersebut. $^{8}$

Indriyanto Seno Adji dalam keterangan ahli di tingkat penyidikan kasus sangkaan korupsi Bibit Slamet Riyanto dan Chandra M. Hamzah berpendapat, bahwa menyalahgunakan kewenangan diartikan sedemikian rupa yaitu : ${ }^{9}$

1. Memiliki kewenangan, tetapi menggunakan kewenangannya lain daripada kewenangan yang ada.

2. Tidak memiliki kewenangan, tetapi melakukan tindakan -tindakan seolaholah memiliki kewenangan.

\footnotetext{
7 Adami Chazawi, Hukum Pidana Korupsi Di Indonesia (Edisi Revisi), RajaGrafindo Persada, Jakarta, 2016, hal. 60.

${ }^{8}$ ibid. hal. 61.

9 OC Kaligis, Korupsi bibit \& Chandra, Indonesia Againts InJustice, Jakarta, 2010 hal.428
} 
3. Melakukan perbuatan atau tindakan dengan menyalahgunakan prosedur untuk mencapai tujuan tertentu.

Tumpang tindih peraturan perundang-undangan di bidang pemberantasan Tindak Pidana Korupsi (Tipikor), merupakan salah satu hambatan utamanya. Padahal pembentukan peraturan perundang-undangan merupakan tahapan pertama dalam upaya pencegahan dan penanggulangan kejahatan dengan sarana "penal", yang perannya tidak kalah penting dengan tugas aparat penegak hukum/penerap hukum. ${ }^{10}$ Kebijakan legislatif merupakan tahap awal yang paling strategis dari keseluruhan dimensi dari tahap ungsionalisasi/operasionalisasi/konkretisa si hukum pidana dan merupakan fundamen aplikasi dan tahap eksekusi. ${ }^{11}$ Kesalahan atau kelemahan dalam pembuatan kebijakan legislasimerupakan kesalahan strategis yang dapat menghambat upaya pencegahan dan penanggulangan kejahatan pada tahap aplikasi dan eksekusinya. ${ }^{12}$

Diundangkannya Undang-Undang Nomor 30 Tahun 2014 tentang Administrasi Pemerintahan (UU Administrasi Pemerintahan), yaitu Pasal 17 sampai dengan Pasal 21 yang mengatur tentang larangan penyalahgunaan wewenang oleh Badan dan/atau Pejabat Pemerintahan serta pemberian kewenangan kepada Aparat Pengawasan Intern Pemerintah (APIP) dan Peradilan TUN (Peradilan

\begin{tabular}{l}
\hline${ }^{10}$ Mahmud Mulyadi, Penanggulangan \\
Tindak Pidana Korupsi Dalam Perspektif \\
Criminal Policy (CorruptionReduction In \\
Criminal Policy Perspective), Jurnal Legislasi \\
Indonesia Vol. 8, No. 2. 2012. \\
11 Lilik Mulyadi, Kompilasi Hukum \\
Pidana Dalam Perspektif Teoritis dan Praktik \\
Peradilan, Mandar Maju, Bandung, 2010, hal. 88. \\
${ }_{12}$ Chaerudin, dkk., Strategi Pencegahan \\
\& Penegakan Hukum Tindak Pidana Korupsi, \\
Cetakan Ke-2, Refika Aditama, Bandung, 2009, \\
hal. 88.
\end{tabular}

Administrasi) untuk melakukan pengawasan dan pengujian mengenai ada atau tidak ada unsur penyalahgunaan Wewenang yang dilakukan oleh Pejabat Pemerintahan.Sementara, sebelumnya telah ada ketentuan Pasal 3 UU Nomor 31 Tahun 1999 tentang Pemberantasan Tindak Pidana Korupsi, sebagaimana telah diubah dengan UU Nomor 20 Tahun 2001 (UU Pemberantasan Tipikor) jo. Pasal 5 dan Pasal 6 UU Nomor 46 Tahun 2009 tentang Pengadilan Tindak Pidana Korupsi (UU Pengadilan Tipikor), yang salah satu unsurnya mengatur Tipikor karena menyalahgunakan kewenangan, dimana kompetensi absolut untuk memeriksa masalah tersebut diberikan kepada Pengadilan Tipikor. Apabila aparatur negara melakukan perbuatan yang dinilai menyalahgunakan kewenangan dan melawan hukum, artinya mana yang akan dijadikan ujian bagi penyimpangan aparatur negara ini, hukum administrasi negara ataukah hukum pidana, khususnya dalam perkara Tindak Pidana Korupsi. Pemahaman yang berkaitan dengan penentuan yurisdiksi inilah yang masih sangat terbatas dalam kehidupan praktik yudisiel. ${ }^{13}$ Hal ini terkait dengan dapat tidaknya dimintakan pertanggungjawaban pidana berdasarkan ketentuan Pasal 3 UU Pemberantasan Tindak Pidana Korupsi terhadap pejabat pemerintahan yang melakukan penyalahgunaan wewenang yang menimbulkan kerugian keuangan negara ini akan semakin meruncing jika ditelaah lebih lanjut Peraturan Mahkamah Agung (PERMA) Nomor 4 Tahun 2015 tentang 18 Pedoman Beracara dalam Penilaian Unsur Penyalahgunaan Wewenang yang dikeluarkan untuk melaksanakan ketentuan Pasal 21 Undang-Undang Administrasi

13 Ridwan H. R, Hukum Administrasi Negara Edisi Revisi, RajaGrafindo Persada, Jakarta, 2010, hal. 376. 
Barhamudin, Penyalahgunaan Kewenangan Pejabat Pemerintahan Dan Ruang Lingkupnya Menurut Undang-Undang Administrasi Pemerintahan, halaman 175-192

Pemerintahan. Di dalam Pasal 2 ayat (1) PERMA Nomor 4 Tahun 2015 disebutkan bahwa pengadilan (tata usaha Negara) berwenang menerima, memeriksa, dan memutus permohonan penilaian ada atau tidak adanya penyalahgunaan wewenang dalam keputusan dan/atau tindakan pejabat pemerintahan sebelum adanya proses pidana.

Ketentuan Pasal 2 ayat (1) PERMA Nomor 4 Tahun 2015 ini tersirat bahwa dalam hal adanya tindakan penyalahgunaan wewenang yang dilakukan oleh Badan dan/atau Pejabat pemerintahan dimungkinkan adanya proses pidana terhadap Pejabat Pemerintahan yang melakukannya, namun apakah proses pidana tersebut terkait dengan penggunaan ketentuan Pasal 3 UU Pemberantasan Tindak Pidana Korupsi atau tidak rumusan Pasal 2 ayat (1) PERMA Nomor 4 Tahun 2015 tersebut tidaklah dijelaskan lebih lanjut.

Konsep "penyalahgunaan wewenang" dalam undang-undang Administrasi Pemerintahan oleh beberapa ahli hukum dipandang sama dengan konsep "menyalahgunakan kewenangan" karena sebagai kompetensi absolut Peradilan Administrasi jabatan dalam undang-undang Pemberantasan Tipikor. Ketentuan tersebut berpotensi menimbulkan sengketa kewenangan absolut antara Peradilan Tipikor dan Peradilan Administrasi. Berdasarkan latar belakang permalasahan diatas, penulis tertarik untuk membahasnya dalam bentuk penelitian dengan judul Penyalahgunaan kewenangan pejabat pemerintahan dan ruang lingkupnya menurut undang-undang Administrasi Pemerintahan

\section{B. Rumusan Masalah}

Berdasarkan latar belakang di atas, maka penulis menguraikan rumusan masalah sebagai berikut: Apakah tolak ukur untuk menentukan unsur penyalahgunaan kewenangan terhadap pejabat pemerintahan yang menimbulkan kerugian keuangan negara menurut undang-undang Administrasi

Pemerintahan?

\section{Tujuan Penelitian}

Untuk mengetahui, mengkaji dan menganalisis dalam menentukan unsur menyalahgunakan kewenangan dalam undang-undang administrasi pemerintahan

\section{Kegunaan Penelitian}

Adapun kegunaan yang ingin dicapai dalam penelitian ini adalah sebagai berikut :

1. Kegunaan Teoritis.

Diharapkan dapat digunakan sebagai referensi bahan kajian sebagai suatu usaha mengembangkan konsep pemikiran secara lebih logis dan sistematis tentang penyalahgunaan kewenangan oleh pemerintah dan tindak pidana korupsi.

2. Kegunaan Praktis

Hasil penelitian ini dapat memberikan acuan dan pemberitahuan terhadap masyarakat tentang bagaimana penegakan hukum di Indonesia terutama dalam pencegahan dan pemberantasan tindak pidana korupsi

\section{E. Metode Penelitian}

Dalam penelitian ini menggunakan penelitian normatif dengan pendekatan yang digunakan dalam penulisan hukum menurut Peter Mahmud Marzuki adalah sebagai berikut: ${ }^{14}$

Pendekatan kasus ( case approach )

Pendekatan perundang-undangan ( statute approach)

Pendekatan historis ( historical approach )

Pendekatan perbandingan ( Comparative approach)

14 Peter Mahmud Marzuki, Penelitian Hukum, Kencana Prenada Media Group, Jakarta, 2011, hal. 93. 
Pendekatan konseptual ( conceptual approach )

Adapun pendekatan yang digunakan dalam penelitian adalah pendekatan perundang-undangan (statute approach), dan Pendekatan konseptual (concept approach) adalah pendekatan yang dilakukan dengan menelaah semua undang-undangdan regulasi yang bersangkut paut dengan isu hukum yang ditangani. Pendekatan konseptual (concept approach) beranjak dari pandangan-pandangan dan doktrindoktrin yang berkembang didalam ilmu hukum. Masih menurut Peter, pendekatan konseptual dilakukan manakala peneliti tidak beranjak dari aturan hukum yang ada. Hal itu dilakukan karena memang belum atau tidak ada aturan hukum untuk masalah yang dihadapi. ${ }^{15}$ Suatu penelitian yang dilakukan dengan cara membaca dan mempelajari berbagai literatur dan peraturan-peraturan yang berhubungan dengan masalah-masalah yang di bahas. Adapun bahan hukum yang dipergunakan terdiri dari 3 macam yaitu :

1. Bahan Hukum Primer, Bahanbahan Hukum yang mengikat seperti : Undang-Undang Dasar Republik Indonesia 1945; Undang-Undang No. 31 Tahun 1999 Jo. Undang-Undang No. 20 Tahun 2001 tentang Pencegahan dan Pemberantasan Tindak Pidana Korupsi; Undang-Undang No. 49 Tahun 2009 Tentang Pengadilan Tindak Pidana Korupsi; UndangUndang No. 30 Tahun 2014 tentang Administrasi Pemerintahan; Peraturan Mahkamah Agung No. 4 Tahun 2015 tentang Pedoman Beracara Dalam Penilaian Unsur Penyalahgunaan Wewenang

2. Bahan Hukum Sekunder. Hukum Sekunder yaitu bahan-bahan yang memberikan penjelasan mengenai

\footnotetext{
15 ibid, Hal. 157.
}

bahan Hukum Primer, seperti hasil karya Ilmiah dan hasil Penelitian.Termasuk juga bukubuku dan Referensi yang relevan berkitan dengan permasalahan yang dikaji berkitan dengan permasalahan perbandingan unsur penyalahgunaan wewenang antara undang-undang tindak pidana korupsi dengan undang-undang administrasi pemerintahan.

3. Bahan Hukum Tersier. Hukum Tersier yaitu Bahan-bahan hukum yang memberikan informasi mengenai bahan Primer dan Sekunder sepeti kamus besar hukum, dan data Internet.

\section{PEMBAHASAN}

Pembangunan nasional merupakan rangkaian upaya mewujudkan tujuan nasiona yang terdapat dalam pembukaan Undang-Undang Dasar 1945 alinera ke-4 yang berbunyi: "Kemudian daripada itu untuk membentuk suatu Pemerintahan Negara Republik Indonesia yang melindungi segenap bangsa Indonesia dan untuk mewujudkan kesehjateraan umum, menceerdaskan kehidupan bangsa dan ikut melaksanakan ketertiban dunia yang berdasarkan kemerdekaan, perdamaian abadi dan keadilan sosial. Upaya pembangunan nasional seringkali terkendala karena perbuatan-perbuatan tercela yang disebut korupsi. Korupsi di Indonesia telah mengakar dan membudaya, bahkan sampai pada titik yang tidak dapat ditolerir. Dalam era ini korupsi yang dilakukan oleh pegawai pemerintah dalam bentuk penyalahgunaan jabatan, telah menimbulkan kerugian yang dialami Negara dalam jumlah yang sudah tidak terhitung lagi dan dapat dipastikan saat ini jumlah tindak pidana korupsi semakin meningkat. ${ }^{16}$

16 Chaerudin, Syaiful Ahmad Dinar, Syarif Fadilah, Strategi Pencegahan \& Penegakan 
Korupsi berasal dari bahasa

Latin: corruption dari kata kerja corrumpere berarti busuk, rusak, menggoyahkan, memutar balik, menyogok. Menurut Transparency International adalah perilaku pejabat publik, baik politikus/ politisi maupun pegawai negeri, yang secara tidak wajar dan tidak legal memperkaya diri atau memperkaya mereka yang dekat dengannya, dengan menyalahgunakan kekuasaan publik yang dipercayakan kepada mereka. ${ }^{17}$ Dalam Kamus Besar Bahasa Indonesia, korupsi secara harfiah berarti: buruk, rusak, suka memakai barang (uang) yang dipercayakan padanya, dapat disogok (melalui kekuasaannya untuk kepentingan pribadi). Hal seperti itu dikemukakan pula oleh Henry Campbell Black, yang mengartikan korupsi sebagai 'an act done with an intent to give some advantage inconsistent with official duty and the right of other"'. (Terjemahan bebas: suatu perbuatan yang dilakukan dengan maksud untuk memberikan suatu keuntungan yang tidak sesuai dengan kewajiban resmi dan hak-hak dari pihak lain).Termasuk pula dalam pengertian "corruption" menurut black adalah, perbuatan seorang pejabat yang secara melanggar hukum menggunakan jabatannya untuk mendapatkan suatu keuntungan yang berlawanan dengan kewajibannya. ${ }^{18}$ Korupsi adalah perbuatan yang melanggar hukum yang menggunakan jabatannya untuk keuntungan sendiri dengan cara

Hukum Tindak Pidana Korupsi, Refika Aditama, Bandung, 2008. hal.20.

Muhammad Shoim, Laporan Penelitian Individual (Pengaruh Pelayanan Publik Terhadap Tingkat Korupsi pada Lembaga Peradilan di Kota Semarang), Pusat Penelitian IAIN Walisongo Semarang, 2009, hal. 14.

${ }^{18}$ Elwi Danil, Korupsi (Konsep, Tindak Pidana, dan Pemberantasannya), RajaGrafindo Persada, Jakarta, 2011, hal. 3. menyalahgunakan kewenangan yang diberikan kepadanya.

Mengenai wewenang H.D. Stout mengatakan sebagai berikut : Bevoegdheid is een begrip uit het bestuurlijke organisatierecht, wat kan worden omschreven als het geheel van regels dat betrekking heft op de verkrijging en uitoefening van bestuursrechtelijke bevoegdhedendoor publiekrechtelijke rechtssubjecten in het bestuursrechtelijke rechsverkeer', (Wewenang adalah pengertian yang berasal dari hukum organisasi pemerintahan, yang dapat dijelaskan sebagai keseluruhan aturan-aturan yang berkenaan dengan perolehan dan penggunaan wewenang pemerintahan oleh subyek hukum public di dalam hubungan hukum publik). ${ }^{9}$ Selanjutnya H.D. Stout, mengatakan bahwa wewenang adalah keseluruhan hak dan kewajiban yang secara eksplisit diberikan oleh pembuat undang-undang kepada subjek hukum publik). Menurut F.P.C.L. Tonnaer kewenangan pemerintahan dalam kaitan ini dianggap sebagai kemampuan untuk melaksanakan hukum positif dan dengan begitu, dapat diciptakan hubungan hukum antara pemerintah dengan warga negara. ${ }^{20}$

Dalam Negara hukum wewenang pemerintahan harus berasal dari hukum atau peraturan perundang-undangan, artinya sumber wewenang bagi pemerintahn adalah peraturan perundang-undangan. Kewenangan yang bersumber dari peraturan perundangundangan tersebut diperoleh melalui tiga cara yaitu atribusi, delegasi, dan mandat. ${ }^{21}$

1. Mengenai atribusi, delegasi, dan mandate ini H.D. Van Wijk/Willem Konijnenbelt mendefinisikan sebagai berikut $:^{22}$ Atribusi adalah

\footnotetext{
${ }^{19}$ Ridwan H. R, Op. Cit, hal. 98.

20 ibid.

21 ibid., hal. 101.

22 ibid., hal. 102.
} 
pemberian

wewenang

pemerintahan oleh pembuat

undang-undang kepada organ pemerintahan.

2. Delegasi adalah pelimbahan wewenang pemerintahan dari satu organ kepada organ pemerintahan lainnya.

3. Mandat terjadi ketika organ pemerintahan mengizinkan kewenangannya dijalankan oleh organ lainnya atas namanya.

Disamping peraturan perundangundangan dalam menjalankan kewenangannya terdapat asas-asas umum pemerintahan yang baik. Asas asas umum pemerintahan yang baik adalah asas yang menjunjung tinggi norma

kesusilaan, norma kepatutan, dan norma hukum untuk mewujudkan penyelenggaraan negara yang bersih dari Kolusi, Korupsi, dan Nepotisme, dalam Pasal 3 UU No. 28 Tahun 1999 disebutkan beberapa asas umum penyelenggara negara, yaitu sebagai berikut: ${ }^{23}$

1. Asas kepastian hukum, yaitu asas dalam negara hukum yang mengutamakan landasan peraturan perundang-undangan, kepatutan, dan keadilan dalam setiap kebijakan penyelenggara negara.

2. Asas tertib penyelenggaraan negara, yaitu asaa yang menjadi landasan keteraturan, keserasian, dan keseimbangan dalam pengendalian penyelenggara negara.

3. Asas kepentuingan umum, yaitu asas yang mendahulukan kesejahteraaan umum dengan cara yang aspiratif, akomodatif, dan selektif.

4. Asas keterbukaan, yaitu asas yang membuka diri terhadap hak masyarakat untuk memperoleh

${ }^{2324}$ ibid., hal. 241. informasi yang benar, jujur, dan tidak diskriminatif tentang penyelenggaraan negara dengan tetap memperhatikan perlindungan atas hak asasi pribadi, golongan, dan rahasia negara.

5. Asas proporsionalitas, yaitu asas yang mengutamakan keseimbangan antara hak dan kewajiban penyelenggara negara.

6. Asas Profesionalitas, yaitu asas yang mengutamakan keahlian yang berlandaskan kode etik dan ketentuan peraturan perundangundangan yang berlaku.

7. Asas Akuntabilitas, yaitu asas yang menentukan bahwa setiap kegiatan dan hasil akhir dari kegiatan penyelenggara Negara harus dapat dipertanggungjawabkan kepada masyarakat atau rakyat sebagai pemegang kedaulatan tertinggi Negara sesuai dengan ketentuan peraturan perundang-undangan yang berlaku.

Sebagaimana diketahui adanya ketertkaitan konsep wewenang dalam hukum administrasi dan tindak pidana korupsi. Hukum administrasi berada pada norma hukum pemerintahan dan norma hukum pidana. Norma hukum pidana memiliki sanksi pidana, sedangkan norma hukum pemerintahan berdasarkan hukum administrasi yang sifatnya preventif akan tetapi pada hukum administrasi juga terdapat ketentuan pidana. Hukum administrasi menyangkut norma wewenang pemerintah, penggunaan wewenang, oleh pemerintah dan perlindungan hukum oleh pemerintah baik secara preventif ataupun represif terhadap individu dan masyarakat.

Pada hakekat Hukum administrasi adalah hukum yang berkaitan dengan wewenang pemerintah dan kontrol terhadap penggunaan wewenang yang tujuannya untuk melindungi individu dan 
masyarakat. Hukum administrasi dari aspek preventif merupakan instrument hukum utama berkaitan dengan tiga dimensi, yaitu pertama hukum untuk norma pemerintahan terutama menyangkut wewenang pemerintahan, kedua, hukum oleh tindakan pemerintahan baik yang sifatnya regulasi ataupun yang konkrit, dan ketiga, hukum terhadap perlindungan hukum bagi rakyat. Philipus $M$ Hadjon dan Titiek Sri Djatmiati menyatakan bahwa dari aspek represif, hukum administrasi sangat dominan karena tindak pidana korupsi hanya mungkin terjadi dalam konteks kerugian keuangan negara yang diakibatkan oleh maladministrasi dalam penggunaan wewenang, bentuk maladministrasi yang paling utama adalah penyalahgunaan wewenang. Abdul Latif, maladministrasi berkaitan dengan tindak pidana korupsi adalah bentuk suatu perbuatan yang menyimpang dari penggunaan wewenang oleh pejabat pemerintahan yang diberi sanksi pidana. Karena itu dari aspek tindak pidana korupsi maladministrasi dalam bentuknya penyalahgunaan wewenang adalah merupakan salah satu unsur dari tindak pidana korupsi yang merupakan perbuatan melawan hukum yang bertentangan dengan peraturan perundang-undangan yang berlaku dan asas-asas hukum yang bertentangan dengan norma-norma yang berlaku dalam kehidupan masyarakat berbangsa dan bernegara.

Ada pula yang berpandangan bahwa perbuatan penyalahgunaan wewenang yang sebelumnya merupakan ranah hukum administrasi atau dalam upaya hukum preventif telah bertansformasi sedemikian rupa menjadi perbuatan menyalahgunakan kewenangan dalam ranah hukum pidana yang mana menjadi upaya hukum represif dalam penegakan tindak pidana korupsi, serta berkaitan dengan asas bahwa hukum pidana yang merupakan ultimum remedium atau upaya terakhir sebagai control terhadap penyalahgunaan kewenangan. Bertransformasinya penyalahgunaan wewenang dalam ranah hukum administrasi menjadi menyalahgunakan kewenangan dalam hukum pidana tidak terlepas dengan terpenuhinya faktor atau unsur didalam ketentuan hukum pidana itu sendiri yakni Pasal 3 UUTPK. ${ }^{24}$

Penyalahgunaan wewenang

(detournement de pouvoir) menurut Philipus M Hadjon adalah penggunaan wewenang tidak sebagaimana mestinya. Dalam hal ini pejabat menggunakan wewenangnya untuk tujuan lain yang menyimpang dari tujuan yang telah diberikan kepada wewenang itu. $^{25}$ Sedangkan, Jean Rivero dan Waline mengartikan penyalahgunaan wewenang dalam hukum administrasi diartikan menjadi 3 (tiga) bentuk yaitu :

1. Penyalahgunaan wewenang untuk melakukan tindakan-tindakan yang bertentangan dengan kepentingan umum untuk menguntungkan kepentingan pribadi, kelompok atau golongan.

2. Penyalahgunaan wewenang dalam arti tindakan penjabat tersebut adalah benar diajukan untuk kepentingan umum, tetapi menyimpang dari tujuan apa kewenangan tersebut diberikan oleh undang-undang atau peraturan-peraturan lainnya.

3. Penyalahgunaan wewenang dalam arti penyalahgunaan prosedur yang seharusnya dipergunakan untuk mencapai tujuan tertentu, tetapi telah menggunakan prosedur lain

\footnotetext{
${ }^{24}$ http://www.justitialawfirm.or.id/index.p hp/82-menyalahgunakan-kewenangan-dalamtindak-pidana-korupsi-dan-penyalahgunaanwewenang-pada-hukum-administrasi. diakses pada tanggal 17 maret 2019.

25 Philipus M .Hadjon, dkk, Hukum Administrasi dan Good Governance. Universitas Trisakti, Jakarta, 2012, hal. 25-26.
} 
Barhamudin, Penyalahgunaan Kewenangan Pejabat Pemerintahan Dan Ruang Lingkupnya Menurut Undang-Undang Administrasi Pemerintahan, halaman 175-192

agar terlaksana. ${ }^{26}$ Dalam UndangUndang Administrasi Pemerintahan UUAP pasal 17 mengkategorikan bentuk penyalahgunaan wewenang yaitu a) Melampaui wewenang, jika keputusan dan/atau tindakan yang dilakukan melampaui masa jabatan atau batas waktu berlakunya wewenang, melampaui batas wilayah berlakunya wewenang dan/atau bertentangan dengan ketentuan peraturan perundang-undangan b) Mencampuradukan wewenang, jika keputusan dan/atau tindakan yang dilakukan diluar cakupan bidang atau materi wewenang yang diberikan dan/atau bertentangan dengan tujuan wewenang yang diberikan c) Bertindak sewenang-wenang, jika keputusan dan/atau tindakan yang dilakukan tanpa dasar kewenangan bertentangan dengan putusan pengadilan yang berkekuatan hukum tetap.

Diterbitkannya undang-undang administrasi pemerintahan kemudian menempatkan pengadilan tata usaha Negara (PTUN) untuk menguji ada atau tidak adanya penyalahgunaan wewenang yang dilakukan oleh pejabat sebelum adanya proses pidana. Hal ini akan menimbulkan dualisme pengujian unsur penyalahgunaan wewenang, sebagaimana dalam undang-undang tindak pidana korupsi Pasal 3 mengatur mengenai korupsi karena menyalahgunakan kewenangan yang dimana selama ini merupakan domain pengadilan tindak pidana korupsi. Penyalahgunaan wewenang yang dilakukan oleh pejabat dapat tercermin dari keputusan tata usaha

\footnotetext{
26 Indriyanto Seno Adji,Korupsi, Kebijakan Aparatur Negara dan Hukum Pidana, Diadit Media, Jakarta, 2009, hal. 35.
}

negara sebagaimana yang tercantum dalam Pasal 1 angka 3 UU No. 5 Tahun 1986 jo UU no. 9 Thn 2004 jo UU No. 51 Tahun 2009, adalah : Keputusan Tata Usaha Negara adalah suatu penetapan tertulis yang dikeluarkan oleh Ba-dan atau Pejabat Tata Usaha Negara yang be-risi tindakan hukum Tata Usaha Negara yang berdasarkan peraturan perundangundangan yang berlaku, yang bersifat konkret, individual dan final, yang menimbulkan akibat hukum bagi seseorang atau badan hukum perdata.

Setelah keluarnya UU No. 30 Tahun 2014 tentang Adminitrasi Pemerintahan, Keputusan Tata Usaha Negara sebagaimana tercantum dalam Pasal 1 angka 3 UU No. 5 Tahun 1986, harus dimaknai sebagaimana tercantum Pasal 87 UU No.30 Tahun 2014, yaitu :

a. penetapan tertulis yang juga mencakup tindaan faktual;

b. Keputusan Badan dan/atau Pejabat Tata Usaha Negara di lingkungan eksekutif, legislatif, yudikatif dan penyelenggara negara lainnya;

c. berdasarkan ketentuan undangundang dan AUPB;

d. bersifat final dalam arti luas;

e. Keputusan yang berpotensi menimbulkan akibat hukum, dan/ atau;

f. Keputusan yang berlaku bagi warga masyarakat.

Pasal 5 Undang-Undang No.30 Tahun 2014 menyatakan bahwa Penyelenggaraan Administrasi Pemerintahan berdasarkan:

a. asas legalitas;

b. asas pelindungan terhadap hak asasi manusia; dan

c. AUPB.

Menurut Pasal 10 ayat (1) Undang-Undang No.30 Tahun 2014 tentang Adminitrasi Pemerintahan AsasAsas Umum Pemerintahan yang Baik meliputi asas:

a. kepastian hukum;

b. kemanfaatan; 
c. ketidakberpihakan;

d. kecermatan;

e. tidak menyalahgunakan

kewenangan;

f. keterbukaan;

g. kepentingan umum; dan

h. pelayanan yang baik.

Adanya perluasan pengertian Keputusan Tata Usaha Negara sebagai obyek sengketa perlu dilakukan, hal ini dimulai dari ide pemikiran bahwa: Pertama, UU No. 30 Tahun 2014 tentang Administrasi Pemerintahan berkedu dukan sebagai hukum materiil dalam Sistem Peradilan Tata Usaha Negara, sehingga harus memberi arti yang jelas, batasan dan pemahaman mengenai obyek sengketa Peradilan Tata Usaha Negara. Kedua, pengerti-an Keputusan Tata Usaha Negara yang harus dimaknai secara luas ini, diharapkan dapat mengikuti perkembangan praktek penyelenggaraan negara yang bersifat dinamis. Ketiga, dengan diberinya makna yang lebih luas terhadap Keputusan Tata Usaha Negara, agar dapat tercapai keseimbangan, keserasian, ke-selarasan hubungan antara kepentingan per-seorangan dengan kepentingan umum, serta agar dapat diwujudkan keadilan bagi kedua belah pihak.

Untuk dapat memaknai Keputusan Tata Usaha Negara sebagaimana yang diatur Pasal 87 UU No. 30 Tahun 2014, dapat digunakan interpretasi sistematis atau logis dan interpretasi ekstensif. Kedua interpretasi dapat digunakan secara bersama-sama, karena undang-undang tidak memberikan batasan atau pedoman untuk melakukan penafsiran terhadap undang-undang. Adakalanya Hakim menerapkan interpretasi futuristis apabila yang pemecahan suatu masalah menggunakan rancangan undangundang. ${ }^{27}$

\footnotetext{
${ }^{27}$ Mertokoesumo, Sudikno. 2007. Cet.ke5. Penemuan Hukum. Yogyakarta: Liberty. Hal. 62
}

Menurut UU ini, berkaitan dengan penyalahgunaan wewenang seperti diskresi hanya dapat dilakukan oleh Pejabat Pemerintahan yang berwenang, dengan tujuan untuk: a. Melancarkan penyelenggaraan pemerintahan; $b$. Mengisi kekosongan hukum; dan c. Mengatasi stagnasi pemerintahan dalam keadaan tertentu guna kemanfaatan dan kepentingan umum. Diskresi dimaksud meliputi:

a. Pengambilan Keputusan $\begin{array}{lr}\begin{array}{l}\text { dan/atau } \\ \text { berdasarkan } \\ \text { peraturan }\end{array} & \begin{array}{r}\text { Tindakan } \\ \text { ketentuan }\end{array} \\ \text { undangan yang } & \text { memberikan } \\ \text { suatu pilihan Keputusan } & \text { Kemban } \\ \text { dan/atau Tindakan; } \\ \text { Pengambilan Keputusan } \\ \text { dan/atau Tindakan karena } \\ \text { peraturan perundang- } \\ \text { undangan tidak mengatur; }\end{array}$

c. Pengambil Keputusan dan/atau Tndakan karena peraturan perundang-undangan tidak lengkap atau tidak jelas; dan d. Pengambilan Keputusan dan/atau Tindakan karena adanya stagnasi pemerintahan guna kepentingan yang lebih luas.

Pejabat Pemerintahan yang menggunakan Diskresi harus memenuhi syarat sesuai dengan tjuan Diskresi, tidak bertentangan dengan ketentuan peraturan perundang-undangan, sesuai dengan AUPB, berdasarkan alasan-alasan yang objektif, tidak menimbulkan Konflik Kepentingan, dan dilakukan dengan itikad baik," bunyi Pasal 24 UU ini. Adapun penggunaan Diskresi yang berpotensi mengubah alokasi anggaran wajib memperoleh persetujuan dari Atasan Pejabat sesuai dengan ketentuan peraturan perundang-undangan. Persetujuan dimaksud dilakukan apabila penggunaan Diskresi menimbulkan akibat hukum yang berpotensi membebani keuangan 
negara. dalam hubungan pemberantasan tindak pidana korupsi sebagai berikut: ${ }^{28}$

- Ketua Mahkamah Agung Republik Indonesia

dalam sambutannya pada Seminar

Nasional IKAHI dalam Rangka Hut IKAHI ke 62 dijakarta 26 Maret 2015: Mekanisme penegakan hukum terhadap penyelengggara Negara yang melakukan tindak pidana korupsi yang didalamnya terdapat unsur "Penyalahgunaan Kewenangan" melalui pengadilan tindak pidana korupsi (Tipikor), dan harus dipertanggungjawabkan secara hukum menurut prosedur penyelesaian diranah hukum administrasi. Debgan demikian ada dua dikotomi ranah hukum, yaitu hukum administrasi dan hukum pidana korupsi dalam praktek penyelesaian perkara penyalahgunaan wewenang secara keilmuan hukum dapat menimbulkan dua akibat: Pertama, terhadap perkara yang sama, dalam hal ini penyalahgunaan wewenang, tetapi penyelesaian dilakukan oleh dua ranah hukum public yang berbeda cabang keilmuannya, konsekuensinya, tentu dapat mengahasilkan putusan yang berbeda. Kedua, adanya dikotomi tersebut menimbulkan kesulitan dalam mencapai suatu kebenaran (The Objectivity) yang komprehensif.

Guntur Hamzah, Latar belakang dibentuknya Undang-Undang Republik Indonesia Nomor 30 Tahun 2014 tentang Administrasi Pemerintahan, diantaranya adalah untuk mengatasi problem kriminalisasi kebijakan, karena adakalanya dalam praktek kesalahan pejabat pemerintahan hanya melakukan kesalahan yang sifatnya administrasi (tidak melakukan korupsi serupiah pun),

http://www.justitialawfirm.or.id/index.php/83penyalahgunaan-wewenang-menurut-undangundang-republik-indonesia-nomor-30-tahun-2014tentang-administrasi-pemerintahan-dalampemberantasan-tindak-pidana-korupsi akan tetapi dianggap melakukan tindakan pidana. Dasar Pemikiran utama UndangUndang Republik Indonesia Nomor 30 Tahun 2014 tentang Administrasi Pemerintahan: Kebutuhan untuk menjamin standar proses pengambilan keputusan; Membangun system komunikasi timbal balik antara warga Negara dengan pejabat pemerintahan dalam reformasi birokrasi. Rezim Undang-Undang Republik Indonesia Nomor 30 Tahun 2014 tentang Administrasi Pemerintahan, sudah memasuki rezim atau generasi dimana hubungan komunikasi timbal balik warga Negara dengan badan dan / atau pejabat pemerintahan, terutama dalam melakukan pelayanan public. Dalam pemberantasan korupsi dapat ditinjau dari dua rezim hukum, yaitu rezim HAN (Hukum Administrasi Negara) lebih mengutamakan preventif, sedangkan rezim hukum pidana merupakan upaya tindakan represif. Pada saat UndangUndang Republik Indonesia Nomor 30 Tahun 2014 tentang Administrasi Pemerintahan didesain tidak ada perbedaan prinsipil atau subtantif antara wewenang dan kewenangan, yang ada hanya perbedaan gradual. Perbedaan gradual, bahwa ketika yang melakukan kewenangan maka addessat-nya adalah lembaga, dan apabila yang menjalankan itu pejabat pemerintahan maka itu merupakan wewenang. Jadi, kalau ada perbedaan atau dipisahkan antara wewenang dan kewenangan akan menimbulkan kontradiksi-kontradiksi.

Menurut Andhi Nirwanto, titik Singgung antara hukum pidana dengan HAN (Hukum Administrasi Negara) bukan hanya dalam Undang-Undang Republik Indonesia Nomor 20 Tahun 2001 tentang Perubahan atas UndangUndang Republik Indonesia Nomor 31 Tahun 1999 tentang Pemberantasan Tindak Pidana Korupsi dengan UndangUndang Republik Indonesia Nomor 30 Tahun 2014 tentang Administrasi 
Pemerintahan, tetapi juga dengan UU Keuangan Negara, UU Perbendaharaan Negara, maupun UU BPK. Secara teori dan praktik pembentukan peraturan perundang-undangan, HAN sudah memasuki wilayah hukum pidana maupun hukum perdaat. Bahkan dibeberapa Negara (Amerika, Inggris, dan Belanda) berdasarkan hasil penelitian, bahwa penyelesaian tindak pidana adakalanya diselesaikan melalui sarana HAN, seperti kasus Penyuapan dalam proyek penanaman kapas transgenic di amerika melanggar foreign action act akan tetapi penegak hukum disana, yaitu department of justice dengan security action commission menyelesaikan masalah kerugian Negara dengan denda sebesar US 1,5 juta. Kebebasan (Diskresi) yang dilakukan pejabat pemerintahan tidak dapat dilakukan sebebas-bebasnya, tetapi secara limitative dibatasi oleh peraturan perundang-undangan, dan wewenang mengandung hak dan kewajiban sehingga dapat dinilai oleh hukum. Problematic atau dilematis yang ada dalam UU tipikor dan UUAP, meliputi dua hal yang berbeda yaitu masalah wewenang dan masalah kewenangan. Wewenang adalah berupa hak badan dan/atau Pejabat Pemerintahan atau penyelenggara lainnya untuk mengambil keputusan dan/atau tindakan dalam menyelenggarakan pemerintahan (Pasal 1 angka 5 UUAP), sedang kewenangan merupakan kekuasaan badan dan/atau pejabat pemerintahan atau penyelenggara lainnya untuk bertindak dalam ranah hukum public (Pasal 1 angka 6 UUAP). Adapun ranah PTUN adalah penyalahgunaan wewenang, sedangakan ranah hukum tindak pidana korupsi adalah penyalahgunaan kewenangan (Pasal 3 UU Tipikor). Unsur penyalahgunaan kewenangan Pasal 3 UU Tipikor bersifat alternative, karena selaian penyalahgunaan wewenang juga kesempatan dan sarana yang ada padanya karena jabatan adalah unsur tindak pidana korupsi. Penyalahgunaan kewenangan pada dasarnya merupakan perbuatan melawan hukum (dalam artian tindak pidana) harus disertai dengan adanya mens rea (berniat jahat). Bentuk konkret mens rea adanya actus reus berupa fraud, conflict of interest, dan illegality, sehingga merupakan tindak pidana kejahatan. Sedangkan akibat dari penyalahgunaan wewenang dan sewenang-wenang dalam ranah HAN adalah mengakibatkan keputusan pejabat tidak sah dan dapat dibatalkan.

Zudan Arif Fakrulloh, menyatakan bahwa, Undang-Undang Republik Indonesia Nomor 30 Tahun 2014 tentang Administrasi Pemerintahan, berada diujung hilir, yang hulunya ada di UU Aparatur Sipil Negara (UU No.5 Tahun 2014), dan tujuannya adalah mewujudkan good governance. Berawal dari UU ASN, kemudian mengalir profesi ASN dibawa ke UU Pemerintahan Daerah (UU No. 23 Tahun 2014), disinilah mulai mengadopsi paradigma restorative justice. Mulai mengedepankan unsur pencegahan dan penindakan dilakukan secara bersamaan, UU Pemda secara eksplisit menyatakan bahwa masyarakat yang keberatan dapat mengadukan kepada Aparat penegak hukum, setelah ada pengaduan aparat penegak hukum berkoordinasi dengan aparat pengawas internal pemerintahan (APIP) seperti: BPKP, Inspektorat Jenderal, atau Inspektorat Provinsi/Kabupaten/Kota. Bila tindakan kesalahan bersifat administrative diselesaikan secara internal, sedangkan bila ada indikasi tindak pidana maka diselesaikan melalui aparat penegak hukum. Konsep penting dalam UndangUndang Republik Indonesia Nomor 30 Tahun 2014 tentang Administrasi Pemerintahan ini sebetulnya hanya ada 4 (empat), yaitu: Tindakan, Keputusan, Wewenang; Kewenangan. Apabila dicermati mengenai konsep tindakan dan/atau keputusan pejabat pemerintahan baik dalam UUAP, UU ASN, dan UU Pemda, sebetulnya sedang dibangun 
Barhamudin, Penyalahgunaan Kewenangan Pejabat Pemerintahan Dan Ruang Lingkupnya Menurut Undang-Undang Administrasi Pemerintahan, halaman 175-192

paradigma baru dalam berhukum antara pendekatan pencegahan, penindakan, dan restorative justice dilakukan secara bersamaan.

Pasal 17 Undang-Undang Republik Indonesia Nomor 30 Tahun 2014 tentang Administrasi Pemerintahan, menyatakan :

(1) Badan dan/atau Pejabat Pemerintahan dilarang menyalahgunakan Wewenang.

(2) Larangan penyalahgunaan Wewenang sebagaimana dimaksud pada ayat (1) meliputi:

a. larangan melampaui Wewenang;

b. larangan mencampuradukkan Wewenang; dan/atau c. larangan bertindak sewenang-wenang.

Menurut Pasal 18 ayat (1) Badan dan/atau Pejabat Pemerintahan dikategorikan melampaui Wewenang sebagaimana dimaksud dalam Pasal 17 ayat (2) huruf a apabila Keputusan dan/atau Tindakan yang dilakukan:

a. melampaui masa jabatan atau batas waktu berlakunya Wewenang;

b. melampaui batas wilayah berlakunya Wewenang; dan/atau

c. bertentangan dengan ketentuan peraturan perundang-undangan.

Dalam ayat (2)Badan dan/atau Pejabat Pemerintahan dikategorikan mencampuradukkan Wewenang sebagaimana dimaksud dalam Pasal 17 ayat (2) huruf b apabila Keputusan dan/atau Tindakan yang dilakukan:

a. di luar cakupan bidang atau materi Wewenang yang diberikan; dan/atau

b. bertentangan dengan tujuan Wewenang yang diberikan.

Badandan/atauPejabatPemerintaha n dikategorikan bertindak sewenangwenang sebagaimana dimaksud dalam
Pasal 17 ayat (2) huruf c apabila Keputusan dan/atau Tindakan yang dilakukan, demikian ditentukan dalam ayat (3) :

a. tanpa dasar Kewenangan; dan/atau

b. bertentangan dengan Putusan Pengadilan yang berkekuatan hukum tetap.

Undang-Undang Republik Indonesia Nomor 30 Tahun 2014 tentang Administrasi Pemerintahan Pasal 19 (1) Keputusan dan/atau Tindakan yang ditetapkan dan/atau dilakukan dengan melampaui Wewenang sebagaimana dimaksud dalam Pasal 17 ayat (2) huruf a dan Pasal 18 ayat (1) serta Keputusan dan/atau Tindakan yang ditetapkan dan/atau dilakukan secara sewenangwenang sebagaimana dimaksud dalam Pasal 17 ayat (2) huruf c dan Pasal 18 ayat (3) tidak sah apabila telah diuji dan ada Putusan Pengadilan yang berkekuatan hukum tetap. Ayat (2) Keputusan dan/atau Tindakan yang ditetapkan dan/atau dilakukan dengan mencampuradukkan Wewenang sebagaimana dimaksud dalam Pasal 17 ayat (2) huruf b dan Pasal 18 ayat (2) dapat dibatalkan apabila telah diuji dan ada Putusan Pengadilan yang berkekuatan hukum tetap.

Menurut Solly Lubis, UU AP merupakan hukum materil HAN, sedangkan sedangkan PTUN banyak mengatur hukum formil HAN. Perlu adanya harmonisasi antara ketentuan yang mengatur unsur penyalahgunaan wewenang/kewenangan dalam UU AP (hukum materil HAN) dan UU Tipikor (hukum materil hukum pidana korupsi). Undang-Undang Administrasi Pemerintahan (UUAP) merupakan Lex Generalis pada dasarnya sebagai upaya dalam rangka untuk meningkatkan pemerintahan yang lebih baik (good governance) yaitu dalam rangka preventif, sedang UU Tipikor merupakan Lex Spesialis dititikberatkan pada tindakan represif. Apakah Undang-Undnang 
Administrasi Pemerintahan (UUAP) ini melemahkan atau menguatkan tindak pidana korupsi? Perlu dilihat dari ketentuan didalamnya apakah UU AP sudah mengatur secara lengkap lingkup tata kerja dan disiplin aparatur pemerintahan yang secara khusus disesuaikan dengan ancaman hukum yang sudah disiapkan dalam UU Tipikor, disisi lain dilihat apakah UU Tipikor sudah diatur norma-norma yang antisipatif terhadap kemungkinan tindakan aparatur pemerintahan yang menyimpang dari lingkup tata kerja dan disiplin yang sudah diatur.

\section{Pasal 7}

(1) Pejabat Pemerintahan berkewajiban untuk menyelenggarakan Administrasi Pemerintahan sesuai dengan ketentuan peraturan perundang-undangan, kebijakan pemerintahan, dan AUPB.

(2) Pejabat Pemerintahan memiliki kewajiban:
a. membuat Keputusan dan/atau Tindakan sesuai dengan kewenangannya;

b. mematuhi AUPB dan sesuai dengan ketentuan peraturan perundang-undangan;

c. mematuhi persyaratan dan prosedur pembuatan Keputusan dan/atau Tindakan;

d. mematuhi Undang-Undang ini dalam menggunakan Diskresi;

e. memberikan Bantuan Kedinasan kepada Badan dan/atau Pejabat Pemerintahan yang meminta bantuan untuk melaksanakan penyelenggaraan pemerintahan tertentu;

f. memberikan kesempatan kepada Warga Masyarakat untuk didengar pendapatnya sebelum membuat Keputusan dan/atau Tindakan sesuai dengan ketentuan peraturan perundang-undangan.

g. memberitahukan kepada Warga Masyarakat yang berkaitan dengan
Keputusan dan/atau Tindakan yang menimbulkan kerugian paling lama 10 (sepuluh) hari kerja terhitung sejak Keputusan dan/atau Tindakan ditetapkan dan/atau dilakukan;

h. menyusun standar operasional prosedur pembuatan Keputusan dan/atau Tindakan;

i. memeriksa dan meneliti dokumen Administrasi Pemerintahan, serta membuka akses dokumen Administrasi Pemerintahan kepada Warga Masyarakat, kecuali ditentukan lain oleh undangundang;

j. menerbitkan Keputusan terhadap permohonan Warga Masyarakat, sesuai dengan hal-hal yang diputuskan dalam keberatan/banding;

k. melaksanakan Keputusan dan/atau Tindakan yang sah dan Keputusan yang telah dinyatakan tidak sah atau dibatalkan oleh Pengadilan, pejabat yang bersangkutan, atau Atasan Pejabat; dan

1. mematuhi putusan Pengadilan yang telah berkekuatan hukum tetap.

Menurut UU 30 Tahun 2014 tentang Administrasi Pemerintahan, Diskresi hanya dapat dilakukan oleh Pejabat Pemerintahan yang berwenang, dengan tujuan untuk: a. Melancarkan penyelenggaraan pemerintahan; $b$. Mengisi kekosongan hukum; dan c. Mengatasi stagnasi pemerintahan dalam keadaan tertentu guna kemanfaatan dan kepentingan umum. Adapun penggunaan Diskresi yang berpotensi mengubah alokasi anggaran wajib memperoleh persetujuan dari Atasan Pejabat sesuai dengan ketentuan peraturan perundangundangan. Persetujuan dimaksud dilakukan apabila penggunaan Diskresi menimbulkan akibat hukum yang berpotensi membebani keuangan negara. III. PENUTUP 
Berdasarkan hal tersebut diatas dapat diambil kesimpulan tolak ukur untuk menentukan adanya penyalahgunaan wewenang menurut hukum administrasi dalam hal ini UUAP terjadi jika aparat atau pejabat pemerintahan melakukan diskresi tanpa melalui prosedur dan tujuan dilakukan tidak dalam ruang lingkup sebgaimana yang telah ditentukan Undang-Undang Republik Indonesia Nomor 30 Tahun 2014 tentang Administrasi Pemerintahan dalam pasal 17 dan pasal 18 meliputi: a.larangan melampaui Wewenang; b. larangan mencampuradukkan Wewenang; c. larangan bertindak sewenang-wenang. d. melampaui masa jabatan atau batas waktu berlakunya Wewenang; e. melampaui batas wilayah berlakunya Wewenang; dan/atau f. bertentangan dengan ketentuan peraturan perundangundangan. $g$ di luar cakupan bidang atau materi Wewenang yang diberikan; dan/atau $h$. bertentangan dengan tujuan Wewenang yang diberikan. Penyalahgunaan wewenang baik menurut hukum administrasi ataupun hukum pidana memiliki ranah hukum masingmasing, Berdasarkan Undang-Undang Republik Indonesia Nomor 30 Tahun 2014 tentang Administrasi Pemerintahan dalam Pasal 19 bahwa Keputusan dan/atau Tindakan yang ditetapkan dan/atau dilakukan dengan melampaui Wewenang tidak sah apabila telah diuji dan ada Putusan Pengadilan yang berkekuatan hukum tetap dan Keputusan dan/atau Tindakan yang ditetapkan dan/atau dilakukan dengan mencampuradukkan Wewenang dapat dibatalkan apabila telah diuji dan ada Putusan Pengadilan yang berkekuatan hukum tetap. Pengujian penyalahgunaan kewenangan ini dimaksudkan untuk melindungi tindakan pejabat negara yang memiliki itikad baik dalam menjalankan kewenangannya. Tindakan pejabat negara yang diputus berdasarkan pengujian bukan merupakan tindakan penyalahgunaan kewenangan maka tindakan tersebut tidak dapat dijadikan dasar untuk Aparat Penegak hukum masuk untuk melakukan penyelidikan ataupun penyidikan tindak pidana korupsi penyalahgunaan kewenangan, sedangkan apabila menurut pengujian di PTUN terdapat unsur penyalahgunaan kewenangan (dengan adanya niat jahat dalam hukum pidana), maka terhadap tindakan pejabat negara tersebut dapat dilakukan penyelidikan ataupun penyidikan tindak pidana korupsi.

\section{DAPTAR PUSTAKA}

Abu Daud Busroh, Ilmu negara, Jakarta, Bumi Aksara, 2001

Artidjo Alkostar, 2008,Mengkritisi Fenomena Korupsi di Parlemen, Jurnal Hukum, Volume 15,.

Prayitno Iman Santosa, PertanggungJawaban Tindak Pidana Korupsi, Alumni, Bandung, 2015,

Jawade Hafidz Arsyad, Korupsi dalam Perspektif HAN (Hukum Administrasi Negara), Jakarta, Sinar Grafika, 2013,

Adami Chazawi, Hukum Pidana Korupsi Di Indonesia (Edisi Revisi), RajaGrafindo Persada, Jakarta, 2016,

OC Kaligis, Korupsi bibit \& Chandra, Indonesia Againts InJustice, Jakarta, 2010

Mahmud Mulyadi, Penanggulangan Tindak Pidana Korupsi Dalam Perspektif Criminal Policy (CorruptionReduction In Criminal Policy Perspective), Jurnal Legislasi Indonesia Vol. 8, No. 2.

Lilik Mulyadi, Kompilasi Hukum Pidana Dalam Perspektif Teoritis dan Praktik Peradilan, Mandar Maju, Bandung, 2010,

Chaerudin, dkk., Strategi Pencegahan \& Penegakan Hukum Tindak Pidana Korupsi, Cetakan Ke- 
Barhamudin, Penyalahgunaan Kewenangan Pejabat Pemerintahan Dan Ruang Lingkupnya Menurut Undang-Undang Administrasi Pemerintahan, halaman 175-192

2, Refika Aditama, Bandung, 2009 ,

Ridwan H. R, Hukum Administrasi Negara Edisi Revisi, Raja Grafindo Persada, Jakarta, 2010 ,

Peter Mahmud Marzuki, Penelitian Hukum, Kencana Prenada Media Group, Jakarta, 2011,

Chaerudin, Syaiful Ahmad Dinar, Syarif Fadilah, Strategi Pencegahan \& Penegakan Hukum Tindak Pidana Korupsi, Refika Aditama, Bandung, 2008. Khaelan, Negara Kebangsaan Pancasila Kultural, Historis, Filosofis, Yuridis, dan Aktualisasinya, Yogyakarta, Paradigma, 2013.

Muhammad Shoim, Laporan Penelitian Individual (Pengaruh Pelayanan Publik Terhadap Tingkat Korupsi pada Lembaga Peradilan di Kota Semarang), Pusat Penelitian IAIN Walisongo Semarang, 2009,

Elwi Danil, Korupsi ( Konsep, Tindak Pidana, dan Pemberantasannya), Raja Grafindo Persada, Jakarta, 2011,

http://www.justitialawfirm.or.id/index.ph p/82-menyalahgunakankewenangan-dalam-tindakpidana-korupsi-danpenyalahgunaan-wewenangpada-hukum-administrasi. diakses pada tanggal 17 maret 2019.

Philipus M .Hadjon, dkk, Hukum Administrasi dan Good Governance. Universitas Trisakti, Jakarta, 2012, .

Indriyanto Seno Adji,Korupsi, Kebijakan Aparatur Negara dan Hukum Pidana, Diadit Media, Jakarta, 2009,
Mertokoesumo, Sudikno Cet.ke-5. Penemuan Hukum. Yogyakarta: Liberty. 2007. http://www.justitialawfirm.or.id/index.ph $\mathrm{p} / 83$-penyalahgunaanwewenang-menurut-undangundang-republik-indonesianomor-30-tahun-2014tentang-administrasipemerintahan-dalampemberantasan-tindak-pidanakorupsi 